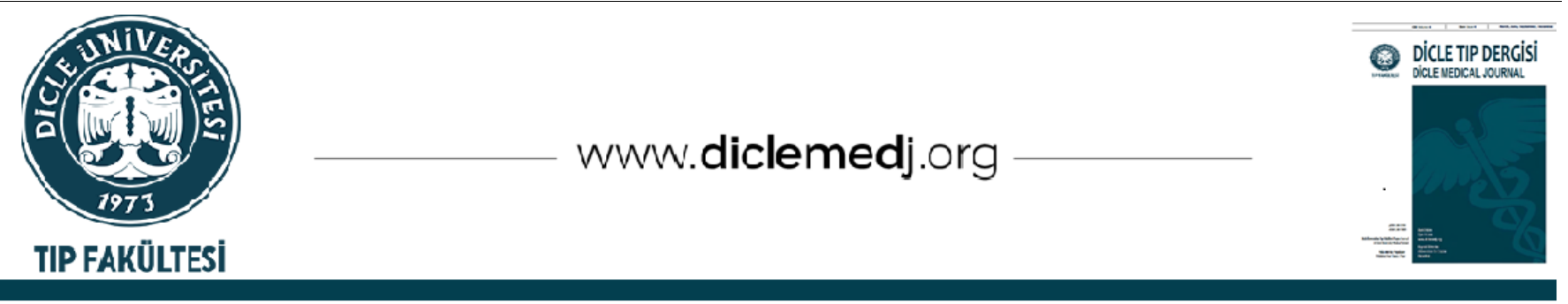

Derleme / Review

\title{
COVID-19 Sürecinde Acil Servis, Hasta Değerlendirme ve Yönetimi
}

\author{
Mehmet Türk ${ }^{1}$, Recep Dursun ${ }^{1}$, Cahfer Güloğlu ${ }^{D}{ }_{1}$ \\ 1 Dicle Üniversitesi Tıp Fakültesi Acil Tıp Anabilim Dalı Diyarbakır, Türkiye \\ Geliş: 01.09.2021; Kabul Tarihi:29.09.2021
}

\section{Öz}

Covid-19 pandemisi sırasında acil servisler hastane ve yerel bakımın ön saflarında yer almaktadır. Hem şüpheli COVID-19 vakalarını belirlemek ve yönetmek hem de diğer tıbbi acil durumları teşhis etmeye ve tedavi etmeye devam etmek için kritik öneme sahiptirler. Sonuç olarak, değişen ihtiyaçları karşılamak için acil servislerin yeniden gözden geçirilmesi gerekmektedir. Bu makalemizde COVID-19 pandemisi sırasında acil servis organizasyonu ve hasta yönetimi süreçlerine odaklanmayı amaçladık.

Anahtar kelimeler: COVID-19, pandemi, acil servis, hasta yönetimi, organizasyon.

\section{Emergency Service, Patient Evaluation and Management During COVID-19}

\section{Abstract}

During the Covid-19 pandemic, emergency services are at the forefront of hospital and local care. They are critical both for identifying and managing suspected cases of COVID-19 and for continuing to diagnose and treat other medical emergencies. As a result, emergency services need to be reconsidered to meet changing needs. In this article, we aimed to focus on emergency service organization and patient management processes during the COVID-19 pandemic.

Keywords: COVID-19, pandemic, emergency department, patient management, organization.

\section{DOI: 10.5798/dicletip.}

Yazışma Adresi / Correspondence: Recep Dursun, Dicle Üniversitesi Tıp Fakültesi Acil Tıp Anabilim Dall, Sur, 21280 Diyarbakır, Türkiye e-mail: drrecepdursun@hotmail.com 


\section{Giriş}

Yüksek morbidite ve mortalite oranlarına sahip yeni koronavirüs (COVID-19) pandemisinde, acil servisler hastane ve toplum bakımının ön saflarında yer almaktadır. Hem şüpheli COVID19 vakaların belirlemek ve tedavi etmek hem de diğer tıbbi acil durumları teşhis etmeye ve tedavi etmeye devam etmek için büyük bir öneme sahiptirler. Pandemilerde artması beklenen hasta yoğunluğuna nasıl karşılık verileceği ve bulaşmanın nasıl sınırlanacağı sorularının yanitlanmasına hazırlanırken rutin cerrahi önemli ölçüde değisşecektir. Bu süreçte en önemli konu kaliteli ve etkin yardım sağlanmasıdır ${ }^{1}$.

\section{ACIL SERVIS PLANLANMASI}

Salgın ve sürekli değişen bir ortamda, idari ekiplerin oluşturulması, altyapı değişiklikleri, COVID-19'lu ve COVID-19 olmayan hastaların yönetimi ve hastaneye yatışları için özel önlemler dahil olmak üzere sürekli değișen planlamalar geliştirilmelidir. Sağlık personeli ve destek personeline eğitim verilirken dijital bilgi teknikleri kullanılarak gelişmeler ve yeni düzenlemeler hakkında günlük bilgi verilmesine özen gösterilmelidir. Bu yaklaşımla temel sağlık hizmetlerinin devamlılığı sağlanırken, COVID-19'un hastane kaynaklı yayılımının başarılı bir șekilde kontrol altına alınmasına da önemli bir katkı sağlanabilir.

Hasta akışını sınırlamak için, hastaların klinik özelliklerini ve epidemiyolojik bilgilerini (seyahat öyküsü dahil) içeren bir yaklaşımla acil servise kabul edilmeden önce ve sonra hastalar triyaj noktalarında taranmalıdır. Bu yaklaşım, risk altındaki kişilerin hızlı bir şekilde belirlenmesine olanak tanırken, uygun olmayan testlerden veya karantinadan geçen kişilerin sayısını da sinırlar.

\section{Hastanemiz acil servisi, COVID-19 pandemisi sırasında üç farklı işlevi yerine getirir:}

1) Pandemi polikliniğinin acil servisine başvuran ve COVID-19 şüphesi ile stabil durumdaki hastaların triyajı,

2) Birinci basamak bakımının sağlanması ve COVID-19 şüphesiyle acil servise başvuran hafif ve şiddetli hastaların hastaneye yatırılması

3) Resüsitasyon, travma, akut zehirlenme gibi diğer standart acil hastalara yardım sağlanması.

Acil serviste klinik semptomların ilk değerlendirmesi triyajın temel taşıdır. Potansiyel olarak enfekte olmuş hastaları etkili bir şekilde tanımlamak ve izole etmek önemlidir.

Acil servise poliklinik ve ambulans kabulü için tek bir ön kapıya sahip olmak, hastaların giriş ve çıkışlarının kontrolünü sağlayacaktır. COVID-19 şüphesi olan stabil hastalar, acil servisin dışında veya acil servis girişinin hemen dışında bulunan bir hazırlık alanında önceden eğitimli sağlık personeli tarafindan taranmalı ve ardından tıbbi yardım alacakları yere nakledilmelidir ${ }^{1}$.

Orta/yüksek riskli veya teyitli COVID-19 hastalarına tıbbi bakımın sağlanacağı acil servis alanı (kontamine acil servis) ve düşük riskli COVID-19 hastalarının tedavi edileceği acil servis alanı (temiz oda acil servisi) ), hem virüsün hastalar arasında bulaşmasını önlemek hem de sağlı̆̆ı iyileştirmek için birbirinden ayrılmalıdır. $\mathrm{Bu}$, enfeksiyonun çalışanlara bulaşma riskini en aza indirmek açısından önemlidir (Şekil 1). İlk kez triyaj yapılan ve COVID-19 açısından düşük riskli olarak değerlendirilen hastaların bakımı, temiz acil servis olarak belirlenmiş bir alanda yapılmalıdır. Enfekte bir acil servis üç alana bölünmelidir: enfekte alan, potansiyel olarak enfekte alan ve temiz alan². 


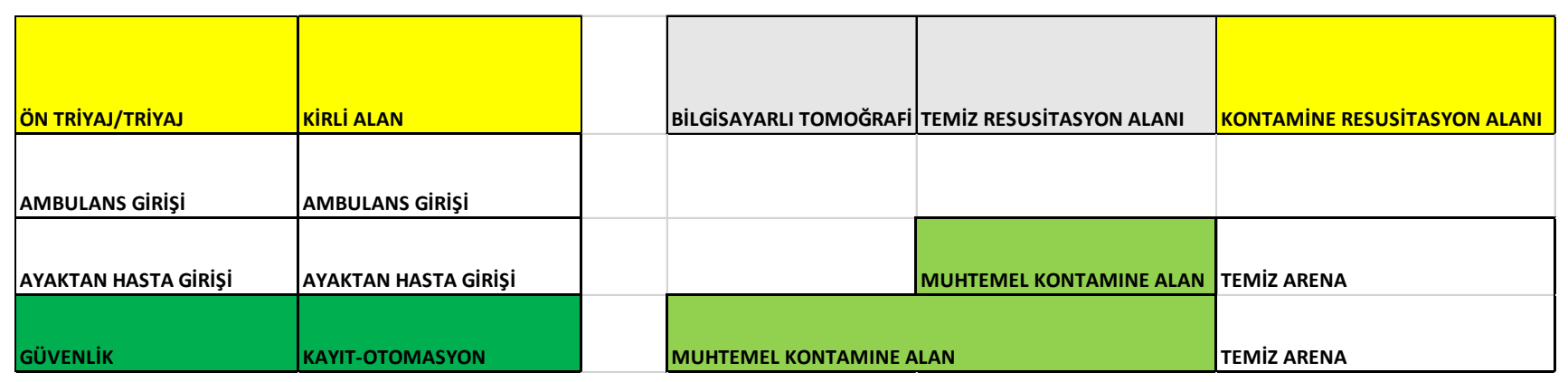

Şekil 1. Dicle Üniversitesi acil servis pandemi planlaması

Acil servis girişinde veya acil servis dişında ön triyaj alanı oluşturulmalıdır. Hastalar diğer tıbbi alanlara alınmadan önce, triyaj öncesi aşamada sağlık personeli tarafından semptomları ve demografik özellikleri (yaş, komorbidite, seyahat ve temas öyküsü) değerlendirilerek pandemi ve pandemi olmayan hastalar arasında bir ayrım yapılmalıdır ${ }^{3}$. Bu değerlendirmede hastaların vital değerleri değerleri not edilmelidir. Bu alandaçalışan sağlık personeline uygun KKE’lar (önlük, FFP3/N95 maske, gözlük, başlık, yüz maskesi) sağlanmalıdır.

Temiz acil servis (düşük riskli hasta bakım alanı)

Ön triyaj alanında muayene edildikten sonra düşük riskli kabul edilen hastalar için muayene, tedavi ve tıbbi bakımın yapıldığı kontamine alandan ayrı bir alandır.

Potansiyel olarak kontamine alan (orta riskli hasta bakım alanı)

Orta riskli, COVID-19 şüphesi olan veya doğrulanmış, başvuru anında vital bulguları stabil olan ve genel durumu iyi olan hastalara tıbbi bakımın sağlandığı alandır².

\section{Yüksek riskli hasta bakım alanı (kontamine alan)}

Hastaneye yatış anında yaşamsal bulguları stabil olmayan, yüksek risk şüphesi olan veya COVID-19 tanısı konmuş hastalara tıbbi bakımın sağlandığı bir alandır². Kontamine alanlarda çalışan sağlık çalışanlarının KKD'yi doğru kullanmaları çok önemlidir. Yüksek riskli hastalar ve tanısı doğrulanmış hastalar mümkünse ayrı alanlarda izole edilmeli, negatif basınçlı alanlarda aerosol dağılımına neden olabilecek işlemler uygulanmalıdır.

\section{ACIL SERVISTE ŞÜPHELI COVID-19 HASTALARININ DEĞERLENDİRILIMESİ}

\section{Klinik özellikler}

COVID-19 enfeksiyonu çok çeşitli semptomlara neden olabilir. En sik görülen vakalar ateş (\%88) ve/veya kuru öksürüktür (\%67). Daha az görülen diğer semptomlar ise yorgunluk (\%38), balgam (\%33), nefes darlığı (\%19), baş ağrısı (\%13), kas ağrısı/artralji (\%15), titreme (\%11), rinit/burun tıkanıklığıdır. \%5), bulantı veya kusma (\%5), ishal (\%4), boğaz ağrısı, koku ve tat duyusunda azalma ${ }^{5}$. Ağır vakalarda pnömoni, böbrek yetmezliği, akut solunum sıkıntısı sendromu ve hatta ölüm gelişebilir.

İlk başta hafif olan semptomlar ikinci haftada daha da kötüleşebilir. Enfeksiyon \%80'inde hafif ila orta, \%14'ünde şiddetli ve $\% 6$ 'sında kritik seyreder. Altmış yaşın üzerindeki kişiler ve hipertansiyon, diyabet, kardiyovasküler hastalık, kronik solunum yolu hastalığı ve kanser gibi altta yatan tıbbi durumları olan kişilerde ciddi hastalık ve ölüm riski daha yüksektir5.

\section{Fizik Muayene}

Fizik muayene bulguları, yaşamsal belirtiler (ateş, solunum hızı, kalp hızı, periferik oksijen satürasyonu ve kan basıncı) dışında genellikle 
spesifik değildir. Hastaların belirgin takipne olmaksızın hipoksik olabileceği ve önemli radyografik bulgulara rağmen akciğer oskültasyon sonuçlarının normal olabileceği bildirilmiştir 5 .

\section{Laboratuvar}

Acil servis muayenelerinin temel amacı, COVID19 enfeksiyonunun ciddiyetini belirlemek ve alternatif tanıları belirlemektir. Genel bir kan testinde lökositoz, lenfopeni, düşük hemoglobin ve trombositopeni görebilirsiniz. Mutlak lenfosit sayısında $(<800 \mu \mathrm{L})$ bir azalma ciddi enfeksiyona katkıda bulunur. D-dimer $(>1000$ $\mathrm{ng} / \mathrm{ml})$, C-reaktif protein $(>100 \mathrm{mg} / \mathrm{L})$, laktatdehidrojenaz ( $>245 \mathrm{U} / \mathrm{L})$, ferritin $(>500$ $\mu \mathrm{g} / \mathrm{L}$ ), kreatinfosfokinaz ( $>2$ kat daha yüksek üst limit) yüksek) ve troponin (üst limitin 2 katından fazla) ciddi COVID-19 enfeksiyonu ile ilişkilidir'6.

\section{Görüntüleme}

Göğüs radyografileri erken veya hafif hastalık için normal olabilir. Yaygın anormal röntgen bulguları, bilateral, periferik ve inferiorpulmoner bölgelerde opaklaşma ve opaklaşmadır.

Amerikan Radyologlar Derneği, COVID-19'u taramak veya teşhis etmek için rutin göğüs BT taramalarının kullanılmamasını ve gerektiğinde hastanede yatan hastalara birakılmasını önermiyor. COVID-19 hastalarında gögüs BT taramaları genellikle viralpnömoni ile ilişkili konsolide anormallikler olsun veya olmasın buzlu cam opasiteleri gösterir. Göğüs BT anormallikleri genellikle iki taraflı, periferik ve genellikle alt lobları içerir. Daha az görülen belirtiler plevral kalınlaşma, plevralefüzyon ve lenfadenopatidir ${ }^{5,6}$.

\section{Sürüntü Örneklerinin Toplanması}

Önce orofaringealsürüntü örnekleri, daha sonra aynı numune çubuğu kullanılarak burun sürüntüleri alınmalı ve soğuk zincirle hazırlanmış nakliye kaplarında uygun KKD giyen belirlenmiş nakliye personeli ile derhal laboratuvara nakledilmelidir ${ }^{4}$.

\section{ACIL DURUM BÖLÜMÜNDE KOVID-19 ŞÜPHELİ HASTALARIN YÖNETIMİ}

\section{Stabil Hastaların Yönetimi}

Acil servise COVID-19 semptom ve bulguları ile başvuran, vital bulguları triyaj alanında stabil olan ve genel durumu iyi olan hastalar, potansiyel olarak enfekte bir bölgeye nakledilmelidir. Öykü, fizik muayene, laboratuvar ve görüntüleme testleri olan hastalar komplike hastalık açısından değerlendirilmelidir.

Ateş, kas/eklem ağrısı, öksürük, boğaz ağrısı ve burun tıkanıklı̆̆l, solunum sıkıntısı ve takipne olmaması, oksijen satürasyonu> \%93 ve eşlik eden durumlar (özellikle kardiyovasküler hastalık, diyabet, hipertansiyon, kanser, kronik akciğer hastalı̆̆ı) gibi belirtiler Diğer 50 yaşından küçük, başvuru sırasında alınan kan testlerinde kötü prognostik kriterleri olmayan ve akciğerlerin normal görüntülenmesi (röntgen ve/veya tomografi) olan immünsüpresif durumlar komplike olmayan hastalık olarak tanımlanır 4 .

Genel durumu iyi, vital bulguları stabil olan ve yatışı planlanmayan bu hasta grubunda yapılan muayeneler sonucunda güncel önerilere göre bir enfeksiyon hastalıkları uzmanı ile ampirik tedaviye başlanır ve eve veya hastaneye gönderilir.

\section{Kritik Hastaların Yönetimi}

Mortalite veya morbiditeye yol açabilen veya mevcut diğer faktörler nedeniyle yakın takip gerektiren hemodinamikinstabilitesi olan veya vital bulguları destekleyici bakım ile stabilizeedilebilen değişken vital bulguları olan hastalar bu grup içinde değerlendirilir. COVID19 şüphesi olan hastalar için hava yolunu ve solunumu açık tutmak çok önemlidir. 


\section{Havayolu Yönetimi}

COVID-19 hastalarında hipoksik solunum yetmezliğinin gerçek insidansı tam olarak bilinmemekle birlikte hastaların \%14'ünde oksijen tedavisi gerektiren ciddi hastalık geliştiği ve \%5'inin mekanik ventilasyon ve yoğun bakım ünitesine ihtiyaç duyduğu bildirilmiştir ${ }^{7}$ Hastalarda hipoksemi gelişiminde pulmoner ödem, hemoglobinopatiler, ventilasyon ve perfüzyon uyumsuzluğu, mikro ve makrovaskülertrombüs gibi çeşitli mekanizmalar desteklenmektedir8. Genellikle oksijen tedavisinin, kronik akciğer hastalığı olmayan hastalar için \%93-96 arasında ve kronik tip II solunum yetmezliği olan hastalar için \%88-92 arasında periferik oksijen satürasyonu (Sp02) sağlayabilen en düşük FiO2 yöntemi kullanılarak sağlanması önerilmektedir ${ }^{9}$.

Aerosolizasyonun önlenmesi COVID-19'un yayılmasında çok önemli bir adım olduğundan, hava yolu yönetimi ve solunum desteği ile hastayı oksijenlendirmek için hangi yöntemin ve nasıl kullanılacağı da kritik öneme sahiptir. Havayolu yönetimi sirasında, non-invaziv mekanik pozitif basınçlı ventilasyon, balon maske ventilasyonu, yüksek akışlı nazal oksijen, düz yüz maskesi ile ilaç nebulizer tedavisi, endotrakealentübasyon, entübasyon öncesi CPR, entübasyonsuzaspirasyontrakea gibi işlemler. kapalı sistemler ve trakeostominin açılması aerosol difüzyonunu artıran prosedürlerdir. Oksijen sağlamak için kullanılan aletlere cerrahi maske takılmasının aerosolizasyonu azalttığına dair net bir kanıt bulunmamakla birlikte, nazal kanül, basit yüz maskesi, rezervuar maske, nazal maske gibi tekniklerin uygulandığı durumlarda bu makineye cerrahi maske takılmasının personel güvenliğini artıracağı ileri sürülmektedir. Ayrıca bronkodilatör tedavisi gereken hastalarda virüsün aerosolizasyonunu azaltmak için nebülizör kullanımından kaçınılmalı ve ölçülü doz inhaler ve spacer kullanılmalıdır5.
Tüm bu girişimler sırasında, müdahale sirasinda uygun KKE ve minimum sayıda personel bulunması zorunludur. Ayrıca hasta mümkün olduğunca negatif basınçlı odaya alınmalı ve izolasyon önlemlerine dikkat edilmelidir. Ancak negatif basınç odası yoksa hasta kapalı yoğun bakım ünitesine transfer edilebilir. Hasta nakledilebiliyorsa, ideal koşullarda ve hava yolu güvenceye alınmış önceden belirlenmiş bir yere nakledilmelidir.

\section{Kardiyak Arrest Yönetimi}

Hastane dışında ve hastanede kardiyak arrest yönetimi çok benzerdir. Hastane dışı kardiyak arrest durumunda, hastane öncesi bakım ekibi tarafindan olay yerinden alınan bir vaka öncelikle ilgili tesise bildirilmelidir. Hastane öncesi bakım ekipleri uygun KKD ile müdahale etmeli ve hastayı acil servise nakletmelidir. Hastane içi kardiyak arrest olan COVID-19 şüphesi olan veya tanısı konan hastalar mümkün olduğunca erken belirlenmelidir.

Acil servise getirilen tüm arrest hastalar bir pandemi sırasında her zaman şüpheli COVID-19 hastaları olarak tedavi edilmelidir ve klinisyenler uygun KKE ile CPR yapmalıdır. Göğsün kompresyonu potansiyel bir aerosol difüzyon prosedürüdür, hava yolu yönetimi ise nihai aerosol difüzyon prosedürüdür. $\mathrm{Bu}$ nedenle uygulayıcı en az bir FFP3 maskesi (FFP2/N95 maskesi değilse), yüz ve göz koruması, uzun su geçirmez önlük ve eldiven kullanmalıdır. $\mathrm{Bu}$, önerilen CPR ve hava yolu prosedürleri için gerekli olan KKD ve diğer malzemelerin hazırlanması ve kontrolü ve bu ekipmanın belirli paketler veya kutularda saklanmasıdır. Hava yolu müdahalesi ciddi bir virüs bulaşma riski taşıdığından balon maske ve endotrakeal tüpe takmak için viral filtreler (HEPA/HME filtreleri) bu ekipmanda saklanmalıdır ${ }^{10 .}$

Çıkar Çatışması Beyanı: Yazarlar çıkar çatışması olmadığını bildirmişlerdir. 
Finansal Destek: Bu çalışma her hangi bir fon tarafından desteklenmemiştir.

Declaration of ConflictingInterests: The authors declared that there is no conflict of interest.

Financial Disclosure: No financial support was received.

\section{KAYNAKLAR}

1. Whiteside T, Kane E, Aljohani B, Alsamman M, Pourmand

A.

Redesigningemergencydepartmentoperationsamid st a viralpandemic. Am J EmergMed. 2020 Apr 15. pii: S0735-6757(20)30262-X. [CrossRef]

2. Oğuz AB, Polat O. COVID-19 Salgınında Acil Servis Organizasyonu ve Triaj. COVID-19 e-kitap. Ed. Memikoğlu O, Genç V. Ankara Üniversitesi Basımevi; 2020: 161-64. Erişim adresi: http://www.medicine.ankara.edu.tr/wpcontent/uploads/sites/121/2020/05/COVID-19Kitap.pdf Erişim tarihi 7 Mayıs 2020.

3. Shen Y, Cui Y, Li N, et at.EmergencyResponsesto Covid-19 Outbreak: ExperiencesandLessonsfrom a General Hospital in Nanjing, China. CardiovascInterventRadiol. 2020 Apr 27. [CrossRef]

4. T.C. Sağlık Bakanlığı Halk Sağlığı Genel Müdürlüğü. COVID-19 (SARS-CoV-2 Enfeksiyonu) Rehberi. Erişim adresi: https://covid19bilgi.saglik.gov.tr/depo/rehberler/ COVID-19_Rehberi.pdf?type=file Erişim tarihi: 18 Nisan 2020.

5. COVID-19 EmergencyDepartmentAssessmentand Management Guideline. Erişim adresi: https://www.edguidelines.com/covid-19resources/covid-19-emergency-department- assessment-and-management-guideline/. Erişim tarihi 3 Nisan 2020.

6. McIntosh K. Coronavirusdisease 2019 (COVID19): Epidemiology, virology, clinicalfeatures, diagnosis, andprevention. UpTo-Date. Updated: Apr, $2020 . \quad$ Erişim adresi: https://www.uptodate.com/contents/coronavirusdisease-2019-covid-19-epidemiology-virology-

clinical-features-diagnosis-and-

prevention?search=Coronavirus $\% 20$ disease $\% 2020$ 19\%20(COVID-

19):\%20Epidemiology,\%20virology,\%20clinical\%2 0features,\%20diagnosis, $\% 20$ and $\% 20$ preventionCo ronavirus $\% 20$ disease $\% 202019 \% 20$ (COVID-

19):\%20Epidemiology,\%20virology,\%20clinical\%2 0features, $\% 20$ diagnosis, $\% 20$ and $\% 20$ prevention\&s ource $=$ search_result $\&$ selectedTitle $=1 \sim 150 \&$ usage_ type $=$ default\&display_rank $=1$

7. Alhazzani W, Moller MH, Arabi YM, Loeb M, Gong MN, Fan E, et al. SurvivingSepsisCampaign: Guidelines on themanagement of criticallyilladultswithcoronavirusdisease 2019 (COVID-19). CritCareMed. 2020 Mar 27. [CrossRef]

8. Wilcox SR. Management of respiratoryfailuredueto covid-19. BMJ. 2020;369:m1786. [CrossRef]

9. Handbook of COVID-19 preventionandtreatment. LIANG T, Editor. Erişim adresi: https://covid19.alibabacloud.com/?spm=a2c65.11461447.0.0.3 36b5272F0SUJy\#J_8102420620 Erişim tarihi 20 Mart 2020.

10. EuropeanResuscitationCouncil COVID-19 Guidelines. Erişim adresi: https://www.erc.edu/sites/5714e77d5e615861f0 0f7d18/content_entry5ea884fa4c84867335e4d1ff /5ea885f34c84867335e4d20e/files/ERC_covid19 pages.pdf?1588257310 Erişim tarihi 7 Mayıs 2020. 